\title{
Resistance induction based on the understanding of molecular interactions between plant viruses and host plants
}

\author{
Md. Shamim Akhter ${ }^{2}$, Kenji S. Nakahara ${ }^{1}$ and Chikara Masuta ${ }^{{ }^{*}}$
}

\begin{abstract}
Background: Viral diseases cause significant damage to crop yield and quality. While fungi- and bacteria-induced diseases can be controlled by pesticides, no effective approaches are available to control viruses with chemicals as they use the cellular functions of their host for their infection cycle. The conventional method of viral disease control is to use the inherent resistance of plants through breeding. However, the genetic sources of viral resistance are often limited. Recently, genome editing technology enabled the publication of multiple attempts to artificially induce new resistance types by manipulating host factors necessary for viral infection.

Main body: In this review, we first outline the two major (R gene-mediated and RNA silencing) viral resistance mechanisms in plants. We also explain the phenomenon of mutations of host factors to function as recessive resistance genes, taking the elF4E genes as examples. We then focus on a new type of virus resistance that has been repeatedly reported recently due to the widespread use of genome editing technology in plants, facilitating the specific knockdown of host factors. Here, we show that (1) an in-frame mutation of host factors necessary to confer viral resistance, sometimes resulting in resistance to different viruses and that (2) certain host factors exhibit antiviral resistance and viral-supporting (proviral) properties.

Conclusion: A detailed understanding of the host factor functions would enable the development of strategies for the induction of a new type of viral resistance, taking into account the provision of a broad resistance spectrum and the suppression of the appearance of resistance-breaking strains.
\end{abstract}

Keywords: Plant-virus interactions, Genome editing, RNA silencing, Plant activators

\section{Background}

Plants are sessile organisms that are continuously affected by numerous abiotic and biotic factors, directly impeding their growth or causing metabolic dysfunction [1-3]. For example, plants are often infected by pathogens such as fungi, bacteria, nematodes, and viruses. Viruses invade all forms of life, and viral infections cause physiological changes in the infected plants, leading to symptoms that

*Correspondence: masuta@res.agr.hokudai.ac.jp

${ }^{1}$ Research Faculty of Agriculture, Hokkaido University, Sapporo, Hokkaido 060-8589, Japan

Full list of author information is available at the end of the article result in significant yield loss. Viruses are undoubtedly difficult to control as they use the host cell machineries for infection. Viral diseases are major limiting factors for sustainable crop production worldwide. Although it is complicated to estimate the overall viral disease-related crop loss, it is estimated to be more than US $\$ 30$ billion annually [4]. Recently, Akhter et al. [5] summarized the significant plant viral disease-related economic loss in important crops in Bangladesh. As obligate intracellular pathogens, viruses are exclusively dependent on the host cell machinery for their survival (e.g., multiplication and cell-to-cell movement), hence they alter host gene expression to suit their needs. Over the past original author(s) and the source, provide a link to the Creative Commons licence, and indicate if changes were made. The images or other third party material in this article are included in the article's Creative Commons licence, unless indicated otherwise in a credit line to the material. If material is not included in the article's Creative Commons licence and your intended use is not permitted by statutory regulation or exceeds the permitted use, you will need to obtain permission directly from the copyright holder. To view a copy of this licence, visit http://creativecommons.org/licenses/by/4.0/. The Creative Commons Public Domain Dedication waiver (http://creativeco mmons.org/publicdomain/zero/1.0/) applies to the data made available in this article, unless otherwise stated in a credit line to the data. 
decade, remarkable progress has been made in understanding the arms race between plants and viruses at the molecular level that could potentially provide new strategies useful for crop improvement programs. Plants with pinpointed disruption of host factors necessary for viral infection could become highly resistant. In this case, the effect of genetic modification on plant growth could be minimized. Furthermore, it might be possible to design plants that do not allow the emergence of resistancebreaking strains. In the following sections, we will outline the known mechanisms of virus resistance in plants, then discuss the newly discovered underlying molecular interactions between the host and viral factors and introduce the possibility of virus resistance induction through modifying plant-virus interaction(s).

\section{Main text \\ Plant-virus interaction-related molecular mechanisms Historical perspective of molecular plant-virus interactions}

Recently developed techniques in plant virology on RNA silencing, such as virus-induced gene silencing, large-scale genomic analysis, and epigenetic analysis, have enriched the understanding of viral pathogenicity and host responses in antiviral resistance. Plant antiviral activities include $R$ gene-mediated resistance, recessive resistance, and antiviral RNA silencing $[6,7] . R$ gene-mediated resistance, the most intensively studied resistance mechanism against bacteria and fungi, generally accompanying hypersensitive response (HR), is also effective in viruses.

The $N$ gene $(N)$, isolated from Nicotiana glutinosa, is the first identified virus-related $R$ gene. The avirulence (Avr) protein recognized by the $\mathrm{N}$ protein against tobacco mosaic virus (TMV) is the viral $126-\mathrm{kDa}$ protein $(126 \mathrm{k})$. The molecular interaction between $\mathrm{N}$ and $126 \mathrm{kDa}$ induces HR-based resistance and subsequently systemic acquired resistance (SAR), supporting the gene-for-gene theory $[8,9]$. When $N$-carrier tobacco plants are infected with TMV, they accumulate salicylic acid (SA), which then induces the expression of the defense-related genes and contributes to the development of SAR in the non-infected parts of the infected plants [10]. Multiple examples for the $R$ genes and their corresponding Avr factors and virus-interacting proteins have been reported for different plant species (Table 1). To explain the sequential interactions between hosts and pathogens, Jones and Dangl [11] proposed the zig-zag model in 2006. In their model, the plant immune system comprises two defense response layers: pathogen-associated molecular pattern (PAMP)triggered immunity (PTI) and effector-triggered immunity (ETI). PTI represents a basic defense mechanism by preventing pathogen invasion in response to specific structures or proteins associated with the pathogen, defined as the so-called PAMPs or microbe-associated molecular patterns. Plants show susceptibility only when a pathogen successfully achieves both the suppression of the PTI response and the production of its pathogenic effectors. ETI, the second level of the defense response, is triggered when the $\mathrm{R}$ gene products directly or indirectly detect the presence of specific effectors. Consequently, an effective ETI would keep plants resistant but insufficient ETI could lead to disease establishment (susceptibility). To explain host-pathogen interactions in $R$ gene-mediated resistance, the guard hypothesis and the decoy model have been proposed in multiple pathosystems [11-13]. Due to the intracellular parasitic viral nature, which absolutely requires a live host cell machinery, any common fungal and bacterial resistance model would not fit viral resistance. Pattern recognition receptors (PRR), which serve as a major defense element by triggering the first layer of resistance [14], cannot play a role in fighting against plant viruses as viruses do not express extracellular PAMPs. However, in the modified zig-zag model [15], RNA silencing is regarded as a major antiviral mechanism for PTI and viral RNA silencing suppressors (RSSs) are regarded as effectors to overcome host RNA silencing. RSSs are then recognized by ETI as a virulence proteins [15].

Recessive resistance is often due to modifications in a certain gene, encoding a host factor critical for viral infection [36]. Recessive resistance might sometimes be provided by a deficiency in a negative regulator for plant defense. For example, several deficient genes of the eukaryotic translation initiation factor (eIF) $4 \mathrm{E}$, eIF4G, and their isoforms are the most widely exploited recessive resistance genes in various plant species and are indeed effective against a subset of viral species [37]. High throughput sequence and genome editing technologies greatly contributed to enhancing plant genetic resources for breeding in various crop species. Multiple recessive resistance genes have been identified in various plant-virus interactions (Table 2).

As viruses are intracellular parasites containing either RNA or DNA genomes in a virion, RNA silencing is considered a major antiviral mechanism $[15,66]$. Successful antiviral RNA silencing results in the degradation of the viral genome at the initial infection site [67]. In addition, several other viral resistance mechanisms have also been reported. These include mechanisms related to the ubiquitin-proteasome machinery, autophagy, and DNA methylation [29, 68, 69]. One interesting example is a tobacco calmodulin-like protein, rgs-CaM, leading to the autophagy-mediated degradation of viral RSSs [70-72]. 
Table 1 Dominant plant virus resistance genes in different host plant species and Avr/viral proteins inducing resistance

\begin{tabular}{|c|c|c|c|c|c|c|}
\hline Virus $^{a}$ & $\begin{array}{l}\text { Avr or viral } \\
\text { protein inducing } \\
\text { resistance }^{b}\end{array}$ & Host Plant & Resistant gene & Resistant protein & Type of resistance ${ }^{c}$ & References \\
\hline TCV & $C P$ & Arabidopsis thaliana & HRT & CC-NB-LRR & $H R$ & {$[16]$} \\
\hline CMV & $\mathrm{CP}$ & A. thaliana & $R C Y 1$ & CC-NB-LRR & $H R$ & {$[17]$} \\
\hline PIAMV & $(-)$ & A. thaliana & $J A X 1$ & Jacalin-like lectin & $\begin{array}{l}\text { Blocking RNA accu- } \\
\text { mulation }\end{array}$ & {$[18]$} \\
\hline PVX & RdRP & A. thaliana & $J A X 1$ & Jacalin Family & $\begin{array}{l}\text { Blocking systemic } \\
\text { movement }\end{array}$ & [19] \\
\hline TEV & $(-)$ & A. thaliana & RTM3 & $\begin{array}{l}\text { MATH-containing } \\
\text { protein }\end{array}$ & Systemic resistance & {$[20]$} \\
\hline CaMV & P1 & A. thaliana & CAR1 & Not identified & $H R$ & {$[21]$} \\
\hline TuMV & UN & Brassica compestris & BCTUR3 & TIR-NB-LRR & Systemic resistance & {$[22]$} \\
\hline TuMV & UN & B. compestris & TuRBOT & CC-NB-LRR & Extreme resistance & {$[23]$} \\
\hline TMV & $C P$ & Capsicum annuum & Llocus & CC-NB-LRR & $H R$ & {$[24]$} \\
\hline PRSV & $(-)$ & Cucumis melo & Prv (Muti alleles) & TIR-NB-LRR & $\mathrm{HR}$ & {$[25]$} \\
\hline $\begin{array}{l}\text { PepMMoV, PepSMV, } \\
\text { PVY }\end{array}$ & $\mathrm{RdRp}$ & C. annuum & Prv4 & CC-NB-LRR & $\mathrm{HR}$ & {$[26]$} \\
\hline CLRDV & Po & Gossypium hirsutum & $c b d$ & TIR-NB-LRR & $\mathrm{HR}$ & {$[27]$} \\
\hline CABMV, TuYV, PLRV & Po & Nicotiana glutinosa & RPO1 & NB-LRR & $\mathrm{HR}$ & {$[28]$} \\
\hline ToYLCV & $\mathrm{V} 1$ and $\mathrm{C} 3$ & Solanum chilense & Ty1/Ty3 (Multi allelle) & RDR & RNA silencing & {$[29]$} \\
\hline ToYLCV & Rep/C1 & S. habrochites & Ty2 & CC-NB-LRR & $H R$ & {$[30]$} \\
\hline TSWV & $\mathrm{NSm}$ & S. lycopersicum & $5 w 5 b$ & NB-ARC-LRR & $H R$ & [31] \\
\hline TSWV & $\mathrm{NSm}$ & N. alata & RTSW & CC-NB-LRR & $H R$ & {$[32]$} \\
\hline PVX & $C P$ & S.tuberosum & $R \times 1$ & CC-NB-LRR & Translation arrest & {$[33]$} \\
\hline PVY & $\mathrm{CP}$ & S. stoloniferum & Rysto & TIR-NB-LRR & $H R$ & [34] \\
\hline MYMV, BCMV & $(-)$ & Vigna mungo & CYR1 & CC-NB-LRR & $\mathrm{HR}$ & {$[35]$} \\
\hline
\end{tabular}

${ }^{a}$ TCV, turnip crinkle virus; CMV, cucumber mosaic virus; PIAMV, plantago asiatica mosaic virus; PVX, potato virus X; TEV, tobacco etch virus; CaMV, cauliflower mosaic virus; TuMV, turnip mosaic virus; TMV, tobacco mosaic virus; PRSV, papaya ringspot virus; PepMMoV, pepper mild mottle virus; PepSMV, pepper severe mosaic virus; PVY, potato virus Y; CLRDV, cotton leaf roll dwarf virus; CABMV, cucurbit aphid borne mosaic virus; PLRV, potato leaf roll virus; ToYLCV, tomato yellow leaf curl virus; TSWV, tomato spotted wilt virus; MYMV, mungbean yellow mosaic virus; BCMV, bean common mosaic virus

${ }^{b}$ Proteins that can bind to R proteins either directly or indirectly. CP, coat protein; RdRP, RNA-dependent RNA polymerase; Po, suppressor of RNA silencing; V1, coat protein of ToYLCV; C1, replication associated protein; C3, replication enhancer protein; Nsm, Non-structural movement protein; (-), Not reported

${ }^{\mathrm{C}} \mathrm{HR}$, hypersensitive response

\section{Resistance conferred by the interactions between $\mathrm{R}$ genes and plant viruses}

Host $R$ genes typically induce race-specific resistance in response to the $A v r$ genes of pathogens [73, 74]. When plant-virus interactions occur in a single cell, an $R$ gene triggers an HR response, a form of programmed cell death that rapidly kills infected cells and restricts the viral invasion. HR is generally associated with various molecular events: the activation and expression of salicylic (SA), jasmonic acid (JA), mitogen-activated protein kinase signaling, calcium ion influx, callose deposition at the plasmodesmata, membrane permeability modification, pathogenesis-related (PR) protein expression, and immediate accumulation of reactive oxygen species (ROS) and nitric oxide (NO) $[75,76]$. The majority of the $R$ genes encode nucleotide-binding (NB) and leucine-rich-repeat (LRR) domains but the Avr proteins do not share any common structure [11]. For the NB-LRR proteins, three domains consist of the center nucleotide-binding site (NBS), an LRR at the C terminal end, and a coiled-coil or Toll and human interleukin receptor (TIR) domain at the N-terminus [77]. The NBS domain also contains the Apaf-1/R protein/CED4 (ARC) domain, thought to be a molecular switch regulating $\mathrm{R}$ protein activation through ATP hydrolysis-related signal transduction [78-81]. The $\mathrm{N}$-terminus displays an important role in the specific interaction with an Avr factor [78]. The NB-LRR-mediated Avr effector recognition, initiating the downstream defense responses, could occur both directly, and indirectly mediated by cellular cofactors.

\section{Resistance conferred by antiviral RNA silencing}

RNA silencing, also known as RNA interference (RNAi) or post-transcriptional gene silencing, is a host plant counter-defense against virus-derived double-stranded 
Table 2 Recessive reistance genes against plant viruses and viral proteins involved in resistance in different host plant species

\begin{tabular}{|c|c|c|c|c|c|}
\hline Virus $^{a}$ & $\begin{array}{l}\text { Viral protein } \\
\text { involved in } \\
\text { resisance }^{b}\end{array}$ & Host plant & Gene/ Locus & Remarks & References \\
\hline $\mathrm{BCMV}$ & $\mathrm{VPg}$ & Phaseolus vulgaris & $b c 3$ & elF 4E (mutagenesis) & [38] \\
\hline CIYVV & Vpg & Pisium sativum & cyv1/cyv2 & elF4E ( mutagenesis) & [39] \\
\hline TEV \&PVY & $\mathrm{VPg}$ & Capsicum spp. & pvr1/pvr2 & elF4E ( mutagenesis) & {$[40]$} \\
\hline RYMoV & Unknown & Oryza sativa & rymv2 & CPR5 homolog & [41] \\
\hline BCMV & Unknown & P. vulgaris & $b c 3$ & elF4E & {$[42]$} \\
\hline BaMMV & $\mathrm{VPg}$ & Hordeum vulgare & rym7 & elF(iso)4E & [43] \\
\hline TuMV & Unknown & Brasssica juncea & retr03 & Mutation of elF2B $\beta$ & {$[44]$} \\
\hline PIAMV & TGB2, TGB3 & Arabidopsis thaliana & $?$ & Mutation of nCBP & {$[45]$} \\
\hline CBSV and UCBSV & $\mathrm{VPg}$ & Manihot esculenta & $?$ & Mutation of $4 \mathrm{E}$ (elF4E) and nCBP & {$[46]$} \\
\hline PVY & $\mathrm{VPg}$ & Nicotina tabacum & va & elF4E (iso) & {$[47]$} \\
\hline $\begin{array}{l}\text { YoMV, ToMV, TMV, } \\
\text { TMGMV, PMMOV }\end{array}$ & & $\begin{array}{l}\text { Nicotiana spp., Solanum lycopersi- } \\
\text { cum, C. annuum, O. sativa }\end{array}$ & TOM1; TOM3 & EMS mutagenesis & {$[37,48]$} \\
\hline PepLCIV, PepLCAV & & C. annuum & pepy 1 & Silencing of CaPelota & [49] \\
\hline ToMV, YoMV & & A. thaliana, N. tabacum & $A R L 8$ & $\begin{array}{l}\text { Simultaneous mutation of } A R L 8 a \\
\text { and } A R L 8 b \text { by T-DNA insertion }\end{array}$ & {$[37,50]$} \\
\hline TuMV, PPV & & $\begin{array}{l}\text { A. thaliana, N. tabacum, Zea mays, } \\
\text { O. sativa, Mesembryanthemum } \\
\text { crystallinum }\end{array}$ & DBP1 & T-DNA mutant & [51] \\
\hline WMV, PPV, BaMV & & $\begin{array}{l}\text { S. Iycopersicum, S. tuerosum, Populus } \\
\text { trichocarpa, Sorghum bicolor, O. } \\
\text { sativa, Tritichum aestivum, Z. mays }\end{array}$ & CPGK & $\begin{array}{l}\text { Natural resistance gene, rwm1 } \\
\text { in Arabibopsis thaliana CVI-0 } \\
\text { ecotype }\end{array}$ & {$[37,52,53]$} \\
\hline PIAMV, PVX, AltMV & & A. thaliana, O. sativa, S. lycopersicum & EXA1 & EMS mutagenesis & [54] \\
\hline TuMV & & $\begin{array}{l}\text { A. thaliana, P. sativum, N. bentha- } \\
\text { miana }\end{array}$ & $P V I P 1, P V I P 2$ & Knockdown mutant of each PVIP & {$[55]$} \\
\hline GFPV, CaMV & & A. thaliana & $P D L P 1, P D L P 2, P D L P 3$ & $\begin{array}{l}\text { Triple mutant of } P D L P 1, P D L P 2 \text { and } \\
P D L P 3 \text { by T-DNA insertion }\end{array}$ & {$[56]$} \\
\hline TuMV & & A. thaliana & PCaP1 & T-DNA mutant & {$[57]$} \\
\hline CaLCuV, TVCV, TuMV & & A. thaliana & SYTA & T-DNA mutant & {$[58,59]$} \\
\hline TuMV & & A. thaliana & $\sec 24 a$ & EMS-induced mutant & {$[60]$} \\
\hline TSWV & & A. thaliana & RHD3 & T-DNA mutant & [61] \\
\hline BaYMV, BaMMV & & All plant species & PDIL5-1 & $\begin{array}{l}\text { Natural resistance gene, rwm11 } \\
\text { in barley }\end{array}$ & {$[62]$} \\
\hline TuMV & & All plant species & IREI & $\begin{array}{l}\text { Double mutation of IREI } a \text { and } \\
\text { IREIb by T-DNA insertion }\end{array}$ & {$[63]$} \\
\hline TuMV, PVX & & All plant species & bZIP60 & T-DNA mutant & {$[37,64]$} \\
\hline CMV & & A. thaliana & HAT1, HAT2, HAT3 & Triple mutant by the HAT genes & {$[65]$} \\
\hline
\end{tabular}

a Abbriviations are explained in Table 1

${ }^{b}$ Viral proteins, which are involved in the resistance associated with elF4E family proteins, are shown

(ds) RNA [82-84]. In the plant-virus interactions, the most common host defense against viruses is considered to be RNA silencing. Antiviral RNA silencing is triggered by viral dsRNA generated either by replication intermediates or by secondary intramolecular RNA folding (hairpin) in the host cells $[85,86]$. In these cells, the viral dsRNAs are cleaved by Dicer-like (DCL) enzymes into virus-induced small RNAs (vsRNAs) [87]. vsRNAs are then incorporated into the RNA-induced silencing complex and guide Argonaute (AGO) proteins to the targeted RNA for degradation or translational arrest [88]. vsRNA, as the antiviral RNA silencing signal, is subjected to the secondary amplification of sRNAs by RNA-dependent RNA polymerase (RDR) 6 and transferred through the plasmodesmata and phloem, inducing systemic viral defense [67]. DNA viruses are also subjected to antiviral RNA silencing [89]. In the co-evolutionary plant-virus interaction context, viruses might have acquired counter-defense mechanisms by suppressing host antiviral silencing [87]. To date, a considerable number of viral RSSs have been already reported [90]. Increasing evidence shows that plants have actually evolved certain 
mechanisms to fight viral RSSs, regarded as countercounter-defense responses in the molecular arms race [88]. Based on the understanding of the RNA silencing mechanisms, we can practically make exogenous applications of viral dsRNA and siRNA for disease protection [91]. Even virus resistance in a transgenic plant expressing a viral sequence is operated by RNA silencing. For example, the coat protein $(\mathrm{CP})$-mediated transgenic papaya resistance against papaya ringspot virus through RNA silencing is one of the success stories in commercial application [92]. Exogenous tomato spotted wilt virus (TSWV)-derived dsRNA application for virus resistance induction in tobacco indicates a promising prospect of spray-induced gene silencing for plant-virus interactions [93].

Resistance conferred by natural variants and manipulation of host susceptible factors for virus infection

Due to their intracellular parasitic nature, viruses are dependent on the host cellular mechanisms for their survival. After the viral entry into the plant cells, the viral genome is released from the capsid, then viral proteins are translated. Due to a limited number of viral-encoded genes, viruses require numerous host factors to pursue a successful infection cycle consisting of replication, transcription, and translation, as well as cell-to-cell and long-distance movement [94]. The absence or modification of a host factor necessary for the virus infection cycle is regarded as an efficient defense approach and is considered a form of passive resistance. Such passive resistance generally exhibits recessive inheritance. For example, eIF4E is a key player in the translation initiation by recruiting messenger RNAs to the ribosomal complex and has been repeatedly identified as an essential host factor for viral infection [94]. Natural variation of eIF4E can confer resistance to crops against potyviruses; the modification of host factors could thus be a common target to develop resistant varieties [95-97]. The known recessive resistance genes are summarized in Table 2.

\section{Manipulation of host factors confer viral resistance How to manipulate host factors: lessons from the manipulation of elF4E family genes}

Until the development of genome editing techniques, site-directed mutagenesis had not been available in plants. T-DNA insertion lines and chemical mutagenbased, such as ethyl methanesulfonate (EMS), random mutagenesis had been an alternative. We present an example of how eIF4E family gene mutations lead to virus resistance. Among five eIF4E family members (eIF4E, eIF4E1b, eIF4E1c, eIF (iso) 4E, and the novel cap-binding protein [nCBP]) in Arabidopsis thaliana, eIF4E, and eIF (iso) $4 \mathrm{E}$ are reportedly involved in potyvirus infection
[98]. In the inoculation tests using the homozygotes of the null alleles, clover yellow vein virus (CIYVV) was found to use eIF4E while turnip mosaic virus (TuMV) uses eIF(iso)4E [99]. Resistance-breaking isolates of TuMV could infect the plant with a single null allele of eIF4E or eIF (iso) $4 E$ as these isolates could use both eIF4E and eIF (iso) 4E [100]. Although eIF4E and eIF(iso) $4 E$ double mutants are not produced due to their fatality, Bastet et al. [100] produced an alternative resistant plant to the resistance-breaking TuMV strains by pyramiding the null allele of $\operatorname{eIF}$ (iso) $4 E$ and the base-edited allele of $e I F 4 E$, mimicking the $e I F 4 E$ resistance allele in pea.

Until recently, nCBP, another eIF4E isoform that is genetically distant to eIF4E and eIF(iso)4E, was not a susceptible factor for viral infection. However, viruses distinct from potyviruses reportedly use nCBP $[45,46]$. T-DNA insertion lines for the $n C B P$ of $A$. thaliana were impaired in the cell-to-cell movement of plantago asiatica mosaic virus, a member of the genus Potexvirus, by inhibiting the expression of the viral movement protein [100]. In cassava plants, the eIF4E family consists of five members (eIF4E, two eIF(iso) $4 E s$, and two $n C B P s$ ). Cassava brown streak virus and Ugandan cassava brown streak virus, members of the genus Ipomovirus, are the causal agents of the cassava brown streak disease. The viral genome-linked proteins (VPg) of these viruses have a higher affinity to nCBPs than eIF4E and eIF(iso)4E. Simultaneous CRISPR/Cas9-mediated genome editing of two $n C B P s$ genes reduced the susceptibility to these viruses in cassava and the severity of symptoms caused by these viruses [46].

\section{Natural variation and in-frame deletion of elF4E1 outstrip the null allele for viral resistance in tomato}

Creating a null allele of a susceptible factor to a virus represents the risk of a potentially detrimental effect on plant growth if the given factor is also essential for the plant. However, for functionally redundant factors, emerging resistance-breaking viruses represent another risk, potentially switching the factor in use from a null to a redundant allele. Moreover, in terms of conferring antiviral resistance, the functional alleles of eIF4E1 carrying non-synonymous base substitutions or a small in-frame deletion reportedly outstripped the null allele in tomato plants [101, 102]. Tomato exhibits two eIF4Es, eIF4E1 and eIF4E2, eIF(iso)4E, and $n C B P$. The natural eIF4E1 allele, pot1, isolated from a wild tomato relative (Solanum habrochaites), reportedly exhibits a wider resistance spectrum against potato virus $\mathrm{Y}$ and tobacco etch virus strains than the corresponding null allele. The null allele was obtained by the TILLING approach with EMSmediated randomly mutated tomato plants [103]. Further analysis demonstrated that the wider resistance spectrum 
by pot 1 was comparable to that by an eIF4E 1 and eIF4E2 double mutant, suggesting that pot1 lacks the function to support viral infection but can compete with eIF4E2 or inhibit its interaction with viruses [102]. The growth defect observed in the double mutant demonstrates the additional usefulness of pot 1 in tomato production.

Recently, we edited eIF4E1 by CRISPR/Cas9 and obtained three alleles, including a nucleotide insertion (IINS) and nine nucleotide deletion (9DEL) within the eIF4E1 protein coding region [101]. IINS, containing a frameshift, is considered to be a null allele, and its homozygote showed resistance to the $\mathrm{N}$ strain of potato virus $\left(\mathrm{PVY}^{\mathrm{N}}\right)$. 9DEL would be a functional allele though it lacks three amino acids. The fact that no significant resistance to $\mathrm{PVY}^{\mathrm{N}}$ was observed in the $9 D E L$ homozygotes indicates that 9DEL retains some function at least partially in $\mathrm{PVY}^{\mathrm{N}}$ infection. Unexpectedly, the $9 D E L$ homozygote but not IINS showed partial resistance to cucumber mosaic virus (CMV), suggesting that the modified function of 9DEL could interfere with CMV infection. Considering the above observations, functional alleles with base-editing or in-frame indels could be occasionally very effective for crop production against viruses.

\section{Modified plant-virus interactions (MPVI)-mediated antiviral resistance}

Genome editing, silencing in transgenic plants, and random mutagenesis mostly result in (partial) loss of function of a particular gene. The primary target genes to confer antiviral resistance would be host susceptible factors, which contribute to viral infection, multiplication, and spread. We list a number of these susceptible factors in Table 2. Host susceptible factors were exhaustively identified using yeast as a host for a plant virus. Two plant viruses, brome mosaic virus and tomato bushy stunt virus, were studied by two research groups [104, 105]. Both studies identified more than a hundred genes affecting virus accumulation, but few were shared in the identified genes between the two studies, indicating that each virus distinctly uses host factors.

In conferring virus resistance by manipulating host factors necessary for the virus, we must understand the viral infection cycle in detail, because some viruses use unusual host factors. There may be inconsistencies in the newly found functions of host factors, given their original functions. For example, as described in the former section, AGO1 is reportedly a core component of RNA silencing as a slicer of its target RNA and involved in antiviral defense. However, AGO1 was recently reported to interact with HC-Pro of potato virus A [106]. This interaction facilitates systemic infection of potato virus A by stabilizing the viral coat protein to form viral particles
[107]. Similarly, a receptor-like kinase, BAM1 was shown to be located at plasmodesmata to facilitate the systemic spread of RNA silencing in A. thaliana while it is also a target protein of $\mathrm{C} 4$, an RNA silencing suppressor of tomato yellow leaf curl virus [108]. In addition, BAM1 was shown to bind to the movement protein of TMV and promote the cell-to-cell movement of TMV at an early stage of infection in $N$. benthamiana [109]. rgs-CaM is reportedly an endogenous RNA silencing suppressor [110], but it works for the defense against CMV by binding to and directing degradation of the viral RNA silencing suppressor $2 \mathrm{~b}$ under activation of SA signaling [70-72, 111].

Although RDR1 and DCL4 are reportedly involved in small RNA biogenesis in antiviral RNA silencing, the loss of function mutation of RDR1 and silencing of $D C L 4$ reduced susceptibility to viruses and potato spindle tuber viroid in $N$. benthamiana $[112,113]$. RDR1 and DCL4 are not visibly susceptible host factors necessary for viruses and viroids but their absence may enhance the RDR6- and DCL2,3-mediated anti-virus and anti-viroid defenses, respectively. In other words, competitive interactions among the redundant RDRs and DCLs may result in these inconsistent host reactions. Another inconsistent host reaction with a susceptible factor was reported recently; hiper-susceptibility to TuMV was observed in the eIF4E null mutant of $A$. thaliana though the eIF4E mutant is resistant to CIYVV [114]. Recently autophagy has been reported to be involved in both antiviral and proviral mechanisms [115-117], suggesting that plants use their gene products flexibly.

Even the defense-related genes can become an effective target to induce antiviral resistance; the genetic resources for antiviral resistance might exceed our expectations. To explore promising host factors and to find how to edit them for the modified-plant-virus interaction (MPVI)mediated antiviral resistance, more knowledge, and research is necessary.

\section{Molecular mechanisms for antiviral resistance induced by plant activators}

Induction of plant resistance, which is achieved either by chemicals (SAR) or by microbes (induced systemic resistance, ISR), is an alternative to manage viral diseases in crops [118]. Phytohormones such as SA, JAs, ethylene (Et), and abscisic acid (ABA) reportedly regulate plant responses against pathogens [119]. A comprehensive list of chemicals to plant viruses has been listed in Table 3. Auxins (Auxs), brassinosteroids (BRs), cytokinins (CKs), and ABA are known for their roles in plant growth and development but have been recently documented to also play a role in plants-virus interactions [120-122]. Interestingly, SA, JA, and Et, which 
Table 3 Plant activators and microbes that induce host resistance against plant viruses

\begin{tabular}{|c|c|c|c|c|c|}
\hline Plant activator and microbe $^{a}$ & Virus $^{b}$ & Host & Resistance & Hormones $^{c}$ & Reference \\
\hline ASM & PIAMV, PVX, TUMV, CCYV & Nicotiana benthamiana, Cucumis melo & Systemic & SA & {$[131,132]$} \\
\hline BABA & TMV & N. tabacum & $\mathrm{HR}$ & SA & [133] \\
\hline \multirow[t]{2}{*}{ Probenazol } & TMV & N. tabacum & $\mathrm{HR}$ & SA & [134] \\
\hline & TMV & N. benthamiana & Systemic & BR & [135] \\
\hline \multirow[t]{2}{*}{ Brassinosteroid } & RSV & Oyaza sativa & Systemic & $\mathrm{JA} / \mathrm{BR}$ & [136] \\
\hline & CMV & Cucurbita pepo & Systemic & $\mathrm{BR}$ & {$[137]$} \\
\hline Chitosan & TBSV & Phaseolus vulgaris & $\mathrm{HR}$ & SA & [138] \\
\hline Quassinoids & TMV & N. tabacum, N. glutinosa & Systemic, HR & Not reported & [139] \\
\hline Quinolizidine alkaloids & TMV & N. tabacum & Systemic & Not reported & [140] \\
\hline Harpin popW & TMV & N. tabacum & $\mathrm{HR}$ & SA & {$[141]$} \\
\hline Soluble silicon & TRSV, TMV & N. tabacum & Systemic & SA & [142] \\
\hline $\begin{array}{l}\text { Esterified whey protein fractions } \\
\text { (EWPF) }\end{array}$ & TMV & N. tabacum & $H R$ & SA & [143] \\
\hline Eudesmanolides & TMV & N. tabacum, N. glutinosa & Systemic, HR & SA & [144] \\
\hline Spermine and longer polyamines & CMV & Arabidopsis thaliana & Systemic & SA & [145] \\
\hline PABA & TMV & Capsicum annuum & Systemic & SA & [146] \\
\hline Eugenol & TYLCV & Solanum lycopersicum & Systemic & SA & {$[147]$} \\
\hline Ningnanmicin & TMV & N. tabacum & Systemic & SA & [148] \\
\hline SHAM & CMV & A. thaliana & Systemic & SA & [149] \\
\hline Ascorobic acid & TuMV & Brassica rapa & Systemic & $J A$ & [150] \\
\hline 2,3-butanediol & CMV, TMV & C. annuum & Systemic & SA/JA/ET & [151] \\
\hline $\begin{array}{l}\text { Bacillus amyloliquefaciens strain } \\
\text { MBl600 }\end{array}$ & TSWV, PVY & S. lycopersicum & Systemic & SA & [152] \\
\hline Bacillus amyloliquefaciens strain 5B6 & BBWV, CMV, PepMoV & C. annuum & Systemic & $\mathrm{SA} / \mathrm{JA}$ & [153] \\
\hline Penicillium simplicissimum & CMV & $\begin{array}{l}\text { A. thaliana, N. tabacum, N. bentha- } \\
\text { miana }\end{array}$ & Systemic & SA/ JA/ET & [154] \\
\hline $\begin{array}{l}\text { Trichoderma harzianum strain T-22 } \\
\text { (T22) }\end{array}$ & CMV & S. lycopersicum & Systemic & SA/JA/ET & {$[155]$} \\
\hline Pseudozyma churashimaensis (Yeast) & CMV, PeMMoV, PeMoV, BBWV & C. annuum & Systemic & SA/JA/ET & [156] \\
\hline
\end{tabular}

a ASM, acibenzolar-S-methyl; BABA, $\beta$ - aminobutyric acid; SHAM, salicylhydroxamic acid; PABA, para-aminobenzoic acid

${ }^{\mathrm{b}}$ Abbreviations are explained in Table 1

${ }^{\mathrm{C}} \mathrm{BR}$, brassinosteroid; SA, salisylic acid; JA, jasmonic acid; ET, ethylene

regulate the defense pathways, exhibit antagonistic interactions with each other. For example, the activation of the SA signaling pathway can repress the JA/Et pathway mainly through the two genes, NPR1 (NONEXPRESSER OF PATHOGENESIS RELATED GENE 1) and WRKY7O, and the ABA pathway through NPR1 or its downstream elements [123-126]. Conversely, the activation of the JA/Et pathway represses the expression of certain genes downstream of the SA signaling via MAPK4 (MITOGEN-ACTIVATED PROTEIN KINASE 4) and JIN2 [124, 127]. However, the SA biosynthesis and its signaling are triggered after viral effectors are recognized by the $\mathrm{R}$ proteins that lead to the incompatible interaction. The activation of the incompatible interaction results in host responses to restrict virus spread from the infection site by inducing HR and the accumulation of ROS and PR proteins [128, 129]. SA is also responsible for the activation of SAR in distal tissues, which minimizes the damage of secondary attacks by the pathogen. In tomato plants, the exogenous application of SA triggers the expression of the SIPR1 gene, inducing resistance to TYLCV [130].

\section{Conclusion}

Modifying the host factors necessary for the virus is interesting to potentially confer viral resistance in plants but no such simple solution is available in reality. For example, if the function of the target host factor is not well understood, the knockout of the corresponding gene might also negatively affect the growth and development of the plant. Until recently, it was impossible to specifically eliminate a target host factor. However, with the 
recent development of genome editing technologies, we are now able to specifically edit various host factors, and some of the resulting edited plants acquire unexpected viral resistance not only to the target virus but also to other viruses. Therefore, the possibility of producing new virus-resistant crops by specifically manipulating host factors based on a good understanding of their functions should be extensively explored.

\begin{abstract}
Abbreviations
elF4E: Eukaryotic translation initiation factor 4E; HR: Hypersensitive response; Avr: Avirulence; SAR: Systemic acquired resistance; TMV: Tobacco mosaic virus; PAMP: Pathogen-associated molecular pattern; PTI: Pathogen triggered immunity; ETI: Effector-triggered immunity; PRR: Pattern recognition receptors; RSSs: Viral RNA silencing suppressors; rgs-CaM: Regulator of gene silencing calmodulin related protein; JA: Jasmonic acid; PR: Pathogenesis-related; ROS: Reactive oxygen species; NO: Nitric oxide; NB: Nucleotide-binding; LRR: Leucine-rich-repeat; NBS: Nucleotide-binding site; TIR: Toll and human interleukin receptor; Apaf-1: Apoptotic protease-activating factor-1; CED 4: Caenorhabditis elegans Death-4; ATP: Adenosine triphosphate; RNAi: RNA interference; dsRNA: Double-stranded RNA; DCL: Dicer-like enzyme; AGO: Argonaute; vsRNA: Viral small RNA; RDR: RNA-dependent RNA polymerase; siRNA: Short interfering RNA; CP: Coat protein; TSWV: Tomato spotted wilt virus; T-DNA: Transfer DNA; EMS: Ethyl methanesulfonate; nCBP: Novel cap-binding protein; CIYVV: Clover yellow vein virus; TuMV: Turnip mosaic virus; VPg: Viral protein genome linked; CRISPR/Cas9: Clustered regularly interspaced short palindromic repeats/ CRISPR-associated protein 9; pot1: Protection of telomere 1; TILLING: Target induced local lesions in genomes; 1 INS: One nucleotide insertion; $9 \mathrm{DEL}$ : Nine nucleotides deletion; PVY: Potato virus Y; CMV: Cucumber mosaic virus; MPVI: Modified plant-virus interactions; HC-pro: Helper component protease; BAM1: Barely any meristem1; SAR: Systemic acquired resistance; ISR: Induced systemic resistance; Et: Ethylene; ABA: Abscisic acid; BR: Brassinosteroids: CKs: Cytokinins; NPR1: Nonexpresser of pathogenesis related gene 1; MAPK: Mitogen-activated protein kinase; SIPR1: Solanum lycopersicum pathogenesis related gene 1; TYLCV: Tomato yellow leaf curl virus; TCV: Turnip crincle virus; PIAMV: Plantago asiatica mosaic virus; PVX: Potato virus X; TEV: Tobacco etch virus; CaMV: Cauliflower mosaic virus; PRSV: Papaya ringspot virus; PepMMoV: Pepper mild mottle virus; PepSMV: Pepper severe mosaic virus; CLRDV: Cotton leaf roll dwarf virus; CABMV: Cucurbit aphid borne mosaic virus; PLRV: Potato leaf roll virus; MYMV: Mungbean yellow mosaic virus; BCMV: Bean common mosaic virus; Nsm: Non-structural movement protein; ASM: Acibenzolar-Smethyl; BABA: $\beta$-Aminobutyric acid; SHAM: Salicylhydroxamic acid; PABA: Para-aminobenzoic acid.
\end{abstract}

\section{Acknowledgements}

The authors would like to thank Enago (www.enago.jp) for the English language review.

\section{Authors' contributions}

MSA, KSN and CM wrote the manuscript. All authors read and approved the final manuscript.

\section{Funding}

Not applicable.

\section{Availability of data and materials \\ Not applicable.}

\section{Declarations}

Ethics approval and consent to participate

Not applicable.

\section{Consent for publication}

Not applicable.

\section{Competing interests}

$\mathrm{CM}$ is the section editor for plant viruses in Virology Journal.

\section{Author details}

${ }^{1}$ Research Faculty of Agriculture, Hokkaido University, Sapporo, Hokkaido 060-8589, Japan. ${ }^{2}$ Plant Pathology Division, Bangladesh Agricultural Research Institute (BARI), Joydebpur, Gazipur 1701, Bangladesh.

Received: 9 July 2021 Accepted: 23 August 2021

Published online: 28 August 2021

\section{References}

1. Rejeb I, Pastor V, Mauch-Mani B. Plant responses to simultaneous biotic and abiotic stress: molecular mechanisms. Plants. 2014;3:458-75.

2. Suzuki N, Rivero RM, Shulaev V, Blumwald E, Mittler R. Abiotic and biotic stress combinations. New Phytol. 2014;203:32-43.

3. Atkinson NJ, Urwin PE. The interaction of plant biotic and abiotic stresses: From genes to the field. J Exp Bot. 2012;63:3523-43.

4. Jones RAC. Global plant virus disease pandemics and epidemics. Plants. 2021;10:233.

5. Akhter MS, Akanda AM, Kobayashi K, Jain RK, Mandal B. Plant virus diseases and their management in Bangladesh. Crop Prot. 2019:118:57-65.

6. Maule AJ, Caranta C, Boulton MI. Sources of natural resistance to plant viruses: status and prospects. Mol Plant Pathol. 2007;8:223-31.

7. Kang BC, Yeam I, Jahn MM. Genetics of plant virus resistance. Annu Rev Phytopathol. 2005;43:581-621.

8. Whitham S, Dinesh-Kumar SP, Choi D, Hehl R, Corr C, Baker B. The product of the tobacco mosaic virus resistance gene $\mathrm{N}$ : similarity to toll and the interleukin-1 receptor. Cell. 1994;78:1101-15.

9. Dinesh-Kumar SP, Tham WH, Baker BJ. Structure-function analysis of the tobacco mosaic virus resistance gene N. Proc Natl Acad Sci USA. 2000;97:14789-14789.

10. Verberne MC, Hoekstra J, Bol JF, Linthorst HJM. Signaling of systemic acquired resistance in tobacco depends on ethylene perception. Plant J. 2003;35:27-32.

11. Jones JDG, Dangl JL. The plant immune system. Nature. 2006:444:323-9.

12. Dangl JL, Jones JDG. Plant pathogens and integrated defence responses to infection. Nature. 2001;411:826-33.

13. Van Der Hoorn RAL, Kamoun S. From guard to decoy: a new model for perception of plant pathogen effectors. Plant Cell. 2008;20:2009-17.

14. Tena G, Boudsocq M, Sheen J. Protein kinase signaling networks in plant innate immunity. Curr Opin Plant Biol. 2011;14:519-29.

15. Nakahara KS, Masuta C. Interaction between viral RNA silencing suppressors and host factors in plant immunity. Curr Opin Plant Biol. 2014;20:88-95.

16. Kang SH, Qu F, Morris TJ. A spectrum of HRT-dependent hypersensitive responses elicited by the 52 amino acid $\mathrm{N}$-terminus of turnip crinkle virus capsid protein and its mutants. Virus Res. 2015;200:30-4.

17. Takahashi H, Shoji H, Ando S, Kanayama Y, Kusano T, Takeshita M, et al. RCY1-mediated resistance to Cucumber mosaic virus is regulated by LRR domain-mediated interaction with $C M V(Y)$ following degradation of RCY1. Mol Plant Microbe Interact. 2012;9:1171-85.

18. Yamaji Y, Maejima K, Ozeki J, Komatsu K, Shiraishi T, Okano Y, et al. Lectin-mediated resistance impairs plant virus infection at the cellular level. Plant Cell. 2012;24:778-93.

19. Yoshida T, Shiraishi T, Hagiwara KY, Komatsu K, Maejima K, Okano Y, et al. The plant noncanonical antiviral resistance protein JAX1 inhibits potexviral replication by targeting the viral RNA-dependent RNA polymerase. J Virol. 2019;93:e01506-e1518.

20. Cosson P, Sofer L, Le QH, Leger V, Schurdi-Levraud V, Whitham SA, et al. RTM3, which controls long-distance movement of potyviruses, is a member of a new plant gene family encoding a meprin and TRAF homology domain-containing protein. Plant Physiol. 2010;154:222-32.

21. Adhab M, Angel C, Leisner S, Schoelz JE. The P1 gene of Cauliflower mosaic virus is responsible for breaking resistance in Arabidopsis thaliana ecotype. Virology. 2018;523:15-21.

22. Ma J, Hou X, Xiao D, Qi L, Wang F, Sun F, et al. Cloning and characterization of the BCTUR3 gene related to resistance to turnip mosaic 
virus (TuMV) from non-heading Chinese cabbage. Plant Mol Biol Rep. 2010;28:588-96.

23. Jin M, Lee SS, Ke L, Kim JS, Seo MS, Sohn SH, et al. Identification and mapping of a novel dominant resistance gene, TuRB07 to Turnip mosaic virus in Brassica rapa. Theor Appl Genet. 2014;127:509-19.

24. Tomita R, Sekine KT, Mizumoto H, Sakamoto M, Murai J, Kiba A, et al. Genetic basis for the hierarchical interaction between Tobamovirus spp. and $L$ resistance gene alleles from different pepper species e-Xtra. Mol Plant Microbe Interact. 2011;24:108-17.

25. Brotman Y, Normantovich M, Goldenberg Z, Zvirin Z, Kovalski I, Stovbun N. Dual resistance of melon to Fusarium oxysporum races 0 and 2 and to Papaya ring-spot virus is controlled by a pair of head-to-head-oriented NB-LRR genes of unusual architecture. Mol Plant. 2013;6:235-8.

26. Kim SB, Lee HY, Seo S, Lee JH, Choi D. RNA-dependent RNA polymerase (NIb) of the potyviruses is an avirulence factor for the broad-spectrum resistance gene Pvr4 in Capsicum annuum cv. CM334. PLoS ONE. 2015;10:e0119639.

27. Agrofoglio YC, Delfosse VC, Casse MF, Hopp HE, Bonacic Kresic I, ZieglerGraff $V$, et al. PO protein of cotton leafroll dwarf virus-atypical isolate is a weak RNA silencing suppressor and the avirulence determinant that breaks the cotton Cbd gene-based resistance. Plant Pathol. 2019;68:1059-71.

28. Wang K, Der Empleo R, Nguyen TTV, Moffett P, Sacco MA. Elicitation of hypersensitive responses in Nicotiana g/utinosa by the suppressor of RNA silencing protein PO from poleroviruses. Mol Plant Pathol. 2015;16:435-48.

29. Butterbach P, Verlaan MG, Dullemans A, Lohuis D, Visser RGF, Bai Y, et al. Tomato yellow leaf curl virus resistance by Ty-1 involves increased cytosine methylation of viral genomes and is compromised by cucumber mosaic virus infection. Proc Natl Acad Sci USA. 2014;111:12942-7.

30. Shen $X$, Yan Z, Wang X, Wang Y, Arens M, Du Y, et al. The NLR protein encoded by the resistance gene $T y-2$ is triggered by the replicationassociated protein Rep/C1 of tomato yellow leaf curl virus. Front Plant Sci. 2020;11:545306

31. Zhu M, Jiang L, Bai B, Zhao W, Chen X, Li J, et al. The intracellular immune receptor $\mathrm{S} w$-5b confers broad-spectrum resistance to tospoviruses through recognition of a conserved 21-amino acid viral effector epitope. Plant Cell. 2017;29:2214-32.

32. Huang C, Liu Y, Yu H, Yuan C, Zeng J, Zhao L, et al. Non-structural protein NSm of tomato spotted wilt virus is an avirulence factor recognized by resistance genes of tobacco and tomato via different elicitor active sites. Viruses. 2018;10:660

33. Richard MMS, Knip M, Schachtschabel J, Beijaert MS, Takken FLW. Perturbation of nuclear-cytosolic shuttling of Rx 1 compromises extreme resistance and translational arrest of potato virus $X$ transcripts. Plant $J$. 2021:106:468-79.

34. Grech-Baran M, Witek K, Szajko K, Witek Al, Morgiewicz K, Wasilewicz-Flis I, et al. Extreme resistance to Potato virus $Y$ in potato carrying the Rysto gene is mediated by a TIR-NLR immune receptor. Plant Biotechnol J. 2020;18:655-67.

35. Maiti S, Paul S, Pal A. Isolation, characterization, and structure analysis of a non-TIR-NBS-LRR encoding candidate gene from MYMIV-resistant Vigna mungo. Mol Biotechnol. 2012:52:217-33.

36. Robaglia C, Caranta C. Translation initiation factors: a weak link in plant RNA virus infection. Trends Plant Sci. 2006;11:40-5.

37. Hashimoto M, Neriya Y, Yamaji Y, Namba S. Recessive resistance to plant viruses: potential resistance genes beyond translation initiation factors. Front Microbiol. 2016;7:1695.

38. Feng X, Myers JR, Karasev AV. Bean common mosaic virus isolate exhibits a novel pathogenicity profile in common bean, overcoming the bc-3 resistance allele coding for the mutated elF4E translation initiation factor. Phytopathology. 2015;105:1487-95.

39. Choi SH, Nakahara KS, Andrade M, Uyeda I. Characterization of the recessive resistance gene cyv1 of Pisum sativum against Cloveryellow vein virus. J Gen Plant Pathol. 2012;78:269-76.

40. Perez K, Yeam I, Kang BC, Ripoll DR, Kim J, Murphy JF, et al. Tobacco etch virus infectivity in Capsicum spp. is determined by a maximum of three amino acids in the viral virulence determinant VPg. Mol Plant Microbe Interact. 2012;25:1562-73.

41. Orjuela J, Deless EF, Kolade O, Cheron S, Ghesquiere A, Albar L. A recessive resistance to Rice yellow mottle virus is associated with a rice homolog of the CPR5 gene, a regulator of active defense mechanisms. Mol Plant Microbe Interact. 2013;26:1455-6143.

42. Naderpour M, Lund OS, Larsen R, Johansen E. Potyviral resistance derived from cultivars of Phaseolus vulgaris carrying $b c-3$ is associated with the homozygotic presence of a mutated elF4E allele. Mol Plant Pathol. 2010;11:255-63.

43. Yang P, Perovic D, Habekuss A, Zhou RN, Graner A, Ordon F, et al. Genebased high-density mapping of the gene rym 7 conferring resistance to Barley mild mosaic virus (BaMMV). Mol Breed. 2013;32:27-37.

44. Shopan J, Mou H, Zhang L, Zhang C, Ma W, Walsh JA, et al. Eukaryotic translation initiation factor 2B-beta (elF2B 3 ), a new class of plant virus resistance gene. Plant J. 2017;90:929-40.

45. Keima T, Hagiwara-Komoda Y, Hashimoto M, Neriya Y, Koinuma $\mathrm{H}$, et al. Deficiency of the elF4E isoform nCBP limits the cell-to-cell movement of a plant virus encoding triple-gene-block proteins in Arabidopsis thaliana. Sci Rep. 2017;7:1-13.

46. Gomez MA, Lin ZD, Moll T, Chauhan RD, Hayden L, Renninger K, et al. Simultaneous CRISPR/Cas9-mediated editing of cassava elF4E isoforms nCBP-1 and nCBP-2 reduces cassava brown streak disease symptom severity and incidence. Plant Biotechnol J. 2019;17:421-34.

47. Ruyi R, Qiang Z, Futai N, Qiu J, Xiuqing W, Jicheng W. Breeding for PVY resistance in tobacco LJ911 using CRISPR/Cas9 technology. Crop Breed Appl Biotechnol. 2021;21:31682116.

48. Kumar S, Dubey AK, Karmakar R, Kini KR, Mathew MK, Prakash HS. Inhibition of TMV multiplication by siRNA constructs against TOM1 and TOM3 genes of Capsicum annuum. J Virol Methods. 2012;186:78-85.

49. Koeda S, Onouchi M, Mori N, Pohan NS, Nagano AJ, Kesumawati E. A recessive gene pepy-1 encoding Pelota confers resistance to begomovirus isolates of PepYLCIV and PepYLCAV in Capsicum annuum. Theor Appl Genet. 2021;134:2947-64.

50. Nishikiori M, Mori M, Dohi K, Okamura H, Katoh E, Naito S, et al. A host small GTP-binding protein ARL8 plays crucial roles in tobamovirus RNA replication. PLoS Pathog. 2011;7:e1002409.

51. Castelló MJ, Carrasco JL, Vera P. DNA-binding protein phosphatase AtDBP1 mediates susceptibility to two potyviruses in Arabidopsis. Plant Physiol. 2010;153:1521-5.

52. Ouibrahim L, Mazier M, Estevan J, Pagny G, Decroocq V, Desbiez C, et al. Cloning of the Arabidopsis rwm 1 gene for resistance to Watermelon mosaic virus points to a new function for natural virus resistance genes. Plant J. 2014;79:705-16.

53. Poque S, Pagny G, Ouibrahim L, Chague A, Eyquard JP, Caballero M, et al. Allelic variation at the rpv 1 locus controls partial resistance to Plum pox virus infection in Arabidopsis thaliana. BMC Plant Biol. 2015;15:159.

54. Hashimoto M, Neriya Y, Keima T, I wabuchi N, Koinuma H, Hagiwara KY, et al. EXA1, a GYF domain protein, is responsible for loss-of-susceptibility to plantago asiatica mosaic virus in Arabidopsis thaliana. Plant $\mathrm{J}$. 2016:88:1120-31.

55. Dunoyer $\mathrm{P}$, Thomas $C$, Harrison $S$, Revers F, Maule A. A cysteine-rich plant protein potentiates Potyvirus movement through an interaction with the virus genome-linked protein VPg. J Virol. 2004;78:2301-9.

56. Amari K, Boutant E, Hofmann C, Schmitt-Keichinger C, FernandezCalvino L, Didier P, et al. A family of plasmodesmal proteins with receptor-like properties for plant viral movement proteins. PLoS Pathog. 2010;6:e1001119.

57. Vijayapalani P, Maeshima M, Nagasaki-Takekuchi N, Miller WA. Interaction of the trans-frame potyvirus protein P3N-PIPO with host protein PCaP1 facilitates potyvirus movement. PLoS Pathog. 2012;8:e1002639.

58. Lewis JD, Lazarowitz SG. Arabidopsis synaptotagmin SYTA regulates endocytosis and virus movement protein cell-to-cell transport. Proc Natl Acad Sci USA. 2010;107:2491-6.

59. Uchiyama A, Shimada-Beltran H, Levy A, Zheng JY, Javia PA, Lazarowitz SG. The Arabidopsis synaptotagmin SYTA regulates the cell-to-cell movement of diverse plant viruses. Front Plant Sci. 2014;5:584.

60. Jiang S, Lu Y, Li K, Lin L, Zheng H, Yan F, et al. Heat shock protein 70 is necessary for Rice stripe virus infection in plants. Mol Plant Pathol. 2014;15:907-17.

61. Feng Z, Xue F, Xu M, Chen X, Zhao W, Garcia-Murria MJ, et al. The ER-membrane transport system is critical for intercellular trafficking of the NSm movement protein and tomato spotted wilt tospovirus. PLoS Pathog. 2016;12:e1005443. 
62. Yang P, Lupken T, Habekuss A, Hensel G, Steuernagel B, Kilian B, et al. PROTEIN DISULFIDE ISOMERASE LIKE 5-1 is a susceptibility factor to plant viruses. Proc Natl Acad Sci USA. 2014;111:2104-9.

63. Zhang L, Chen H, Brandizzi F, Verchot J, Wang A. The UPR branch IRE1-bZIP60 in plants plays an essential role in viral infection and is complementary to the only UPR pathway in yeast. PLoS Genet. 2015:11:e1005164.

64. Ye C, Dickman MB, Whitham SA, Payton M, Verchot J. The unfolded protein response is triggered by a plant viral movement protein. Plant Physiol. 2011;156:741-55.

65. Zou LJ, Deng XG, Han XY, Tan WR, Zhu LJ, Xi DH, et al. Role of transcription factor HAT1 in modulating Arabidopsis thaliana response to Cucumber mosaic virus. Plant Cell Physiol. 2016;57:1879-89.

66. Ketzinel-Gilad M, Shaul Y, Galun E. RNA interference for antiviral therapy. J Gene Med. 2006;8:933-50.

67. Voinnet O. RNA silencing as a plant immune system against viruses. Trends Genet. 2001;17:449-59.

68. Gomes LC, Dikic I. Autophagy in antimicrobial immunity. Mol Cell. 2014;54:224-33.

69. Luo H. Interplay between the virus and the ubiquitin-proteasome system: molecular mechanism of viral pathogenesis. Curr Opin Virol. 2016;17:1-10

70. Nakahara KS, Masuta C, Yamada S, Shimura H, Kashihara Y, Wada TS, et al. Tobacco calmodulin-like protein provides secondary defense by binding to and directing degradation of virus RNA silencing suppressors. Proc Natl Acad Sci USA. 2012;109:10113-8.

71. Jeon EJ, Tadamura K, Murakami T, Inaba J, Kim BM, Sato M, et al. rgsCaM detects and counteracts viral RNA silencing suppressors in plant immune priming. J Virol. 2017;91:e00761-e817.

72. Miyashita Y, Atsumi G, Nakahara KS. Trade-offs for viruses in overcoming innate immunities in plants. Mol Plant Microbe Interact. 2016;29:595-8.

73. Dangl JL, Dietrich RA, Richberg MH. Death don't have no mercy: Cell death programs in plant-microbe interactions. Plant Cell. 1996;8:1793-807.

74. Hammond-Kosack KE, Jones JD. Resistance gene-dependent plant defense responses. Plant Cell. 1996;8:1773-91.

75. Richberg MH, Aviv DH, Dangl JL. Dead cells do tell tales. Curr Opin Plant Biol. 1998;1:480-5.

76. Yang KY, Liu Y, Zhang S. Activation of a mitogen-activated protein kinase pathway is involved in disease resistance in tobacco. Proc Natl Acad Sci USA. 2001;98:741-6.

77. Meyers BC, Kozik A, Griego A, Kuang H, Michelmore RW. Genomewide analysis of NBS-LRR-encoding genes in Arabidopsis. Plant Cell. 2003;15:809-34

78. Collier SM, Moffett P. NB-LRRs work a "bait and switch" on pathogens. Trends in Plant Science. Trends Plant Sci. 2009:14:521-9.

79. Moffett P. Mechanisms of recognition in dominant R gene mediated resistance. Adv Virus Res. 2009;75:1-33.

80. Rairdan GJ, Moffett P. Distinct domains in the ARC region of the potato resistance protein Rx mediate LRR binding and inhibition of activation. Plant Cell. 2006;18:2082-93.

81. Rairdan GJ, Collier SM, Sacco MA, Baldwin TT, Boettrich T, Moffett P. The coiled-coil and nucleotide binding domains of the potato Rx disease resistance protein function in pathogen recognition and signaling. Plant Cell. 2008;20:739-51.

82. Grishok A, Pasquinelli AE, Conte D, Li N, Parrish S, Ha I, et al. Genes and mechanisms related to RNA interference regulate expression of the small temporal RNAs that control C. elegans developmental timing. Cell. 2001;106:23-34.

83. Hammond SM, Caudy AA, Hannon GJ. Post-transcriptional gene silencing by double-stranded RNA. Nat Rev Genet. 2001;2:110-9.

84. Wang MB, Masuta C, Smith NA, Shimura H. RNA silencing and plant viral diseases. Mol Plant Microbe Interact. 2012;25:1275-85.

85. Zhou R, Rana TM. RNA-based mechanisms regulating host-virus interactions. Immunol Rev. 2013;253:97-111.

86. Marathe R, Anandalakshmi R, Smith TH, Pruss GJ, Vance VB. RNA viruses as inducers, suppressors and targets of post-transcriptional gene silencing. Plant Mol Biol. 2000;43:295-306.

87. Ding SW, Voinnet O. Antiviral immunity directed by small RNAs. Cell. 2007;130:413-26.
88. Pumplin N, Voinnet O. RNA silencing suppression by plant pathogens: defence, counter-defence and counter-counter-defence. Nat Rev Microbiol. 2013;11:745-60.

89. Teixeira RM, Ferreira MA, Raimundo GAS, Fontes EPB. Geminiviral triggers and suppressors of plant antiviral immunity. Microorganisms. 2021;9:775

90. Burgyán J, Havelda Z. Viral suppressors of RNA silencing. Trends Plant Sci. 2011;16:265-72.

91. Kim H, Shimura H, Masuta C. Advancing toward commercial application of RNA silencing-based strategies to protect plants from viral diseases. J Gen Plant Pathol. 2019;85:321-8.

92. Tripathi S, Suzuki JY, Ferreira SA, Gonsalves D. Papaya ringspot virus-P: characteristics, pathogenicity, sequence variability and control. Mol Plant Pathol. 2008:9:269-80.

93. Konakalla NC, Bag S, Deraniyagala AS, Culbreath AK, Pappu HR. Induction of plant resistance in tobacco (Nicotiana tabacum) against tomato spotted wilt orthotospovirus through foliar application of dsRNA. Viruses. 2021;13:662.

94. Truniger V, Aranda MA. Recessive resistance to plant viruses. Adv Virus Res. 2009;75:119-59.

95. Schaad MC, Anderberg RJ, Carrington JC. Strain-specific interaction of the tobacco etch virus Nla protein with the translation initiation factor elF4E in the yeast two-hybrid system. Virology. 2000;273:300-6.

96. Yeam I, Cavatorta JR, Ripoll DR, Kang BC, Jahn MM. Functional dissection of naturally occurring amino acid substitutions in elF4E that confers recessive potyvirus resistance in plants. Plant Cell. 2007:19:2913-28

97. Cavatorta JR, Savage AE, Yeam I, Gray SM, Jahn MM. Positive Darwinian selection at single amino acid sites conferring plant virus resistance. J Mol Evol. 2008;67:551-9.

98. Bastet A, Robaglia C, Gallois JL. elF4E resistance: Natural variation should guide gene editing. Trends Plant Sci. 2017;22:411-9.

99. Sato M, Nakahara K, Yoshii M, Ishikawa M, Uyeda I. Selective involvement of members of the eukaryotic initiation factor $4 E$ family in the infection of Arabidopsis thaliana by potyviruses. FEBS Lett. 2005;579:1167-71.

100. Bastet A, Zafirov D, Giovinazzo N, Guyon-Debast A, Nogué F, Robaglia C, et al. Mimicking natural polymorphism in elF4E by CRISPR-Cas9 base editing is associated with resistance to potyviruses. Plant Biotechnol J. 2019;17:1736-50

101. Atarashi H, Kwon J, Jayasinghe WH, Kim H, Taninaka Y, Igarashi M, et al. Artificially edited alleles of the eukaryotic translation initiation factor 4E1 gene differentially reduce susceptibility to cucumber mosaic virus and potato virus $Y$ in tomato. Front Microbiol. 2020;11:564310.

102. Gauffier C, Lebaron C, Moretti A, Constant C, Moquet F, Bonnet G, et al. A TILLING approach to generate broad-spectrum resistance to potyviruses in tomato is hampered by elF4E gene redundancy. Plant J. 2016;85:717-29.

103. Piron F, Nicolaï M, Minoïa S, Piednoir E, Moretti A, Salgues A, et al. An induced mutation in tomato eiF4E leads to immunity to two potyviruses. PLoS ONE. 2010;5:e11313.

104. Panavas T, Serviene E, Brasher J, Nagy PD. Yeast genome-wide screen reveals dissimilar sets of host genes affecting replication of RNA viruses. Proc Natl Acad Sci USA. 2005;102:7326-31.

105. Ishikawa M, Díez J, Restrepo-Hartwig M, Ahlquist P. Yeast mutations in multiple complementation groups inhibit brome mosaic virus RNA replication and transcription and perturb regulated expression of the viral polymerase-like gene. Proc Natl Acad Sci USA. 1997;94:13810-5.

106. Ivanov KI, Eskelin K, Basic M, De S, Lohmus A, Varjosalo M, et al. Molecular insights into the function of the viral RNA silencing suppressor HCPro. Plant J. 2016;85:30-45.

107. Pollari M, De S, Wang A, Makinen K. The potyviral silencing suppressor HCPro recruits and employs host ARGONAUTE1 in pro-viral functions. PLoS Pathog 2020;16:e1008965.

108. Rosas-Diaz T, Zhang D, Fan P, Wang L, Ding X, Jiang Y, et al. A virustargeted plant receptor-like kinase promotes cell-to-cell spread of RNAi. Proc Natl Acad Sci USA. 2018;115:1388-93.

109. Tran PT, Citovsky V. Receptor-like kinase BAM1 facilitates early movement of the Tobacco mosaic virus. Commun Biol. 2021;4:1-11. 
110. Anandalakshmi R, Marathe R, Ge X, Herr JM Jr, Mau C, Mallory A, et al. A calmodulin-related protein that suppresses posttranscriptional gene silencing in plants. Science. 2000;290:142-4.

111. Tadamura K, Nakahara KS, Masuta C, Uyeda I. Wound-induced rgsCaM gets ready for counterresponse to an early stage of viral infection. Plant Signal Behav. 2012;7:1548-51.

112. Ying XB, Dong L, Zhu H, Duan CG, Du QS, Lv DQ, et al. RNA-dependent RNA polymerase 1 from Nicotiana tabacum suppresses RNA silencing and enhances viral infection in Nicotiana benthamiana. Plant Cell. 2010;22:1358-72.

113. Katsarou K, Mavrothalassiti E, Dermauw W, van Leeuwen T, Kalantidis K. Combined activity of DCL2 and DCL3 is crucial in the defense against potato spindle tuber viroid. PLoS Pathog. 2016;12:1-24.

114. Zafirov D, Giovinazzo N, Bastet A, Gallois JL. When a knockout is an Achilles' heel: Resistance to one potyvirus species triggers hypersusceptibility to another one in Arabidopsis thaliana. Mol Plant Pathol. 2021;22:334-47.

115. Clavel M, Michaeli S, Genschik P. Autophagy: a double-edged sword to fight plant viruses. Trends Plant Sci. 2017;22:646-8.

116. Yang M, Ismayil A, Liu Y. Autophagy in plant-virus interactions. Annu Rev Virol. 2020;7:403-19.

117. Kushwaha NK, Hafren A, Hofius D. Autophagy-virus interplay in plants: from antiviral recognition to proviral manipulation. Mol Plant Pathol. 2019;20:1211-6.

118. Faoro F, Gozzo F. Is modulating virus virulence by induced systemic resistance realistic? Plant Sci. 2015;234:1-13.

119. Alazem M, Lin NS. Roles of plant hormones in the regulation of hostvirus interactions. Mol Plant Pathol. 2015;16:529-40.

120. Denance N, Sanchez-Vallet A, Goffner D, Molina A. Disease resistance or growth: the role of plant hormones in balancing immune responses and fitness costs. Front Plant Sci. 2013:4:155.

121. Pieterse CM, Leon-Reyes A, Van der Ent S, Van Wees SC. Networking by small molecule hormones in plant immunity. Nat Chem Biol. 2009;5:308-16.

122. Santner A, Calderon-Villalobos LI, Estelle M. Plant hormones are versatile chemical regulators of plant growth. Nat Chem Biol. 2009;5:301-7.

123. Bari R, Jones J. Role of plant hormones in plant defence responses. Plant Mol Biol. 2009;69:473-88.

124. Koornneef A, Pieterse CMJ. Cross talk in defense signaling. Plant Physiol. 2008;146:839-44.

125. Spoel SH, Koornneef A, Claessens SMC, Korzelius JP, Van Pelt JA, Mueller MJ, et al. NPR1 modulates cross-talk between salicylate- and jasmonate- dependent defense pathways through a novel function in the cytosol. Plant Cell. 2003;15:760-70.

126. Yasuda M, Ishikawa A, Jikumaru Y, Seki M, Umezawa T, Asami T, et al. Antagonistic interaction between systemic acquired resistance and the abscisic acid-mediated abiotic stress response in Arabidopsis. Plant Cell. 2008;20:1678-92.

127. Kachroo A, Kachroo P. Salicylic acid, jasmonic acid and ethylenemediated regulation of plant defense signaling. In: Setlow JK, editor Genetic engineering: Principles and methods. Springer: US; 2007. p. 55-83.

128. Alamillo JM, Saenz P, Garcia JA. Salicylic acid-mediated and RNAsilencing defense mechanisms cooperate in the restriction of systemic spread of plum pox virus in tobacco. Plant J. 2006;48:217-27.

129. Baebler S, Witek K, Petek M, Stare K, Tusek-Znidaric M, Pompe-Novak $\mathrm{M}$, et al. Salicylic acid is an indispensable component of the $\mathrm{Ny}-1$ resistance-gene-mediated response against Potato virus $Y$ infection in potato. J Exp Bot. 2014;65:1095-9.

130. Li T, Huang $Y, X u Z S$, Wang F, Xiong AS. Salicylic acid-induced differential resistance to the Tomato yellow leaf curl virus among resistant and susceptible tomato cultivars. BMC Plant Biol. 2019;19:1-14.

131. Matsuo Y, Novianti F, Takehara M, Fukuhara T, Arie T, Komatsu K. Acibenzolar-s-methyl restricts infection of Nicotiana benthamiana by plantago asiatica mosaic virus at two distinct stages. Mol Plant Microbe Interact. 2019;32:1475-86.

132. Kobayashi Y, Fukuzawa N, Hyodo A, Kim H, Mashiyama S, Ogihara T, et al. Role of salicylic acid glucosyltransferase in balancing growth and defence for optimum plant fitness. Mol Plant Pathol. 2020;21:429-42.
133. Siegrist J, Orober M, Buchenauer H. $\beta$-Aminobutyric acid-mediated enhancement of resistance in tobacco to tobacco mosaic virus depends on the accumulation of salicylic acid. Physiol Mol Plant Pathol. 2000;56:95-106.

134. Nakashita H, Yoshioka K, Yasuda M, Nitta T, Arai Y, Yoshida S, et al. Probenazole induces systemic acquired resistance in tobacco through salicylic acid accumulation. Physiol Mol Plant Pathol. 2002;61:197-203.

135. Deng XG, Zhu T, Peng XJ, Xi DH, Guo H, Yin Y, et al. Role of brassinosteroid signaling in modulating Tobacco mosaic virus resistance in Nicotiana benthamiana. Sci Rep. 2016;6:20579.

136. Hu J, Huang J, Xu H, Wang C, Wen P, You X, et al. Rice stripe virus suppresses jasmonic acid-mediated resistance by hijacking brassinosteroid signaling pathway in rice. PLoS Pathog. 2020;16:e1008801.

137. Tao Y, Yu QX, Zhou YH, Shi K, Zhou J, Yu JQ, et al. Application of 24-epibrassinolide decreases the susceptibility to cucumber mosaic virus in zucchini (Cucurbita pepo L). Sci Hortic. 2015;195:116-23.

138. Gozzo F, Faoro F. Systemic acquired resistance (50 years after discovery): moving from the lab to the field. J Agric Food Chem. 2013;61:12473-91.

139. Yan XH, Chen J, Di YT, Fang X, Dong JH, Sang P, et al. Anti-tobacco mosaic virus (TMV) quassinoids from Brucea javan/ca (L.) merr. J Agric Food Chem. 2010;58:1572-7.

140. Zou J, Zhao L, Yi P, An Q, He L, Li Y, et al. Quinolizidine alkaloids with antiviral and insecticidal activities from the aeeds of Sophora tonkinensis gagnep. J Agric Food Chem. 2020;68:15015-26.

141. Li JG, Cao J, Sun FF, Niu DD, Yan F, Liu HX, et al. Control of Tobacco mosaic virus by PopW as a result of induced resistance in tobacco under greenhouse and field conditions. Phytopathology. 2011;101:1202-8.

142. Zellner W, Frantz J, Leisner S. Silicon delays Tobacco ringspot virus systemic symptoms in Nicotiana tabacum. J Plant Physiol. 2011:168:1866-9.

143. Wang J, Zhu YK, Wang HY, Zhang H, Wang KY. Inhibitory effects of esterified whey protein fractions by inducing chemical defense against tobacco mosaic virus (TMV) in tobacco seedlings. Ind Crops Prod. 2012:37:207-12.

144. Li S, Li Y, Hao X, Li S, He H, Yan X, et al. Eudesmanolides from Wedelia trilobata (L.) Hitchc. as potential inducers of plant systemic acquired resistance. J Agric Food Chem. 2013;61:3884-90.

145. Sagor GHM, Liu T, Takahashi T, Niitsu M, Berberich T, Kusano T. Longer uncommon polyamines have a stronger defense gene-induction activity and a higher suppressing activity of Cucumber mosaic virus multiplication compared to that of spermine in Arabidopsis thaliana. Plant Cell Rep. 2013;32:1477-88.

146. Song GC, Choi HK, Ryu CM. The folate precursor para-aminobenzoic acid elicits induced resistance against Cucumber mosaic virus and Xanthomonas axonopodis. Ann Bot. 2013;111:925-34.

147. Wang C, Fan Y. Eugenol enhances the resistance of tomato against tomato yellow leaf curl virus. J Sci Food Agric. 2014;94:677-82.

148. Han Y, Luo Y, Qin S, Xi L, Wan B, Du L. Induction of systemic resistance against tobacco mosaic virus by Ningnanmycin in tobacco. Pestic Biochem Physiol. 2014;111:14-8.

149. Zhu L, Li Y, Ara N, Yang J, Zhang M. Role of a newly cloned alternative oxidase gene (BjAOX1a) in turnip mosaic virus (TuMV) resistance in Mustard. Plant Mol Bio Rep. 2012;30:309-18.

150. Fujiwara A, Togawa S, Hikawa T, Matsuura H, Masuta C, Inukai T. Ascorbic acid accumulates as a defense response to Turnip mosaic virus in resistant Brassica rapa cultivars. J Exp Bot. 2016;67:4391-402.

151. Kong HG, Shin TS, Kim TH, Ryu CM. Stereoisomers of the bacterial volatile compound 2,3-butanediol differently elicit systemic defense responses of pepper against multiple viruses in the field. Front Plant Sci. 2018;9:90.

152. Beris D, Theologidis I, Skandalis N, Vassilakos N. Bacillus amyloliquefaciens strain MBI600 induces salicylic acid dependent resistance in tomato plants against Tomato spotted wilt virus and Potato virus Y. Sci Rep. 2020;8:10320.

153. Lee GH, Ryu CM. Spraying of leaf-colonizing Bacillus amyloliquefaciens protects pepper from Cucumber mosaic virus. Plant Dis. 2016;100:2099-105.

154. Elsharkawy MM, Shimizu M, Takahashi H, Hyakumachi M. Induction of systemic resistance against Cucumber mosaic virus by Penicillium 
simplicissimum GP17-2 in Arabidopsis and tobacco. Plant Pathol. 2012;61:964-76.

155. Vitti A, Pellegrini E, Nali CS, Lovelli CS, Sofo A, Valerio M, et al. Trichoderma harzianum $\mathrm{T}-22$ induces systemic resistance in tomato infected by Cucumber mosaic virus. Front Plant Sci. 2016;7:1520.

156. Lee G, Lee SH, Kim KM, Ryu CM. Foliar application of the leaf-colonizing yeast Pseudozyma churashimaensis elicits systemic defense of pepper against bacterial and viral pathogens. Sci Rep. 2017;7:39432.

\section{Publisher's Note}

Springer Nature remains neutral with regard to jurisdictional claims in published maps and institutional affiliations.
Ready to submit your research? Choose BMC and benefit from:

- fast, convenient online submission

- thorough peer review by experienced researchers in your field

- rapid publication on acceptance

- support for research data, including large and complex data types

- gold Open Access which fosters wider collaboration and increased citations

- maximum visibility for your research: over $100 \mathrm{M}$ website views per year

At BMC, research is always in progress.

Learn more biomedcentral.com/submissions 